University of New Hampshire

University of New Hampshire Scholars' Repository

Psychology Scholarship

College of Liberal Arts (COLA)

6-1-2015

\title{
The personality systems framework: Current theory and development
}

John D. Mayer

University of New Hampshire, Durham, jack.mayer@unh.edu

Follow this and additional works at: https://scholars.unh.edu/psych_facpub

Comments

This is an Author's Manuscript of an article published by Elsevier in Journal of Research in Personality in 2015,

available online: https://dx.doi.org/10.1016/j.jrp.2015.01.001. This manuscript version is made available under the CC-BY-NC-ND 4.0 license http://creativecommons.org/licenses/by-nc-nd/4.0/

\section{Recommended Citation}

Mayer, J. D. (2015). The personality systems framework: Current theory and development. Journal of Research in Personality, 56, 4-14.

This Article is brought to you for free and open access by the College of Liberal Arts (COLA) at University of New Hampshire Scholars' Repository. It has been accepted for inclusion in Psychology Scholarship by an authorized administrator of University of New Hampshire Scholars' Repository. For more information, please contact Scholarly.Communication@unh.edu. 
The Personality Systems Framework:

Current Theory and Development

John D. Mayer

University of New Hampshire

Author Notes. The author wishes to thank Jayne Allen, Bonnie Barlow, Jennifer M. Demers, Brendan Lortie, Kimberly Phillips and Kateryna Sylasaka, and the reviewers and editors of this special issue for their comments on earlier drafts of this article. All correspondence regarding this article can be addressed to John D. Mayer, Department of Psychology, McConnell Hall, 15 Academic Way, University of New Hampshire, Durham, NH 03824; email:

jack.mayer@unh.edu.

\begin{abstract}
The personality systems framework is a fieldwide outline for organizing the contemporary science of personality. I examine the theoretical impact of systems thinking on the discipline and, drawing on ideas from general systems theory, argue that personality psychologists understand individuals' personalities by studying four topics: (a) personality's definition, (b) personality's parts (e.g., traits, schemas, etc.), (c) its organization and (d) development. This framework draws on theories from the field to create a global view of personality including its position and major areas of function. The global view gives rise to new theories such as personal intelligence - the idea that people guide themselves with a broad intelligence they use to reason about personalities.
\end{abstract}

\title{
Prepublication version of:
}

Mayer, J. D. (2015). The personality systems framework: Current theory and development. Journal of Research in Personality, 56, 4-14. 
The Personality Systems Framework: Current Theory and Development

Personality psychologists ask a variety of questions about personality: "How do we perceive one another?" "What do we know about ourselves?" "What are our goals?" (Emmons \& King, 1988; Vazire \& Mehl, 2008; Zebrowitz, 2006). Research on these topics has yielded many intriguing findings about how we form impressions of one another, evaluate traits, and form opinions of our potential for change (Andersen \& Chen, 2002; Goldberg \& Rosolack, 1994; Plaks, Levy, \& Dweck, 2009). Contemporary theorists draw together related research findings to help explain them, but their theories rarely provide a picture of the whole personality - nor do they aim to. By comparison, the personality systems framework provides a contemporary view of the whole personality system. This article describes the framework, its rationale, and how it depicts personality.

The personality systems framework began as an outline of the field created to organize the discipline's theories and research in a systematic and integrated fashion. I used the term "framework" to convey my aspiration to be "theory-neutral" —or at least "theory-light" - in organizing others' theories and personality research in a fair and balanced manner (Mayer, 2007b; Mayer \& Allen, 2013; Mayer, 2014b). As the "systems" in the name suggested, the framework originally drew on general systems theory for its foundation. Since first introducing the framework, however, I have added touches of evolutionary theory and sociological perspectives to further develop and enrich how the framework envisions personality.

Von Bertalanffy's General Systems

Theory maintained that all systems, from cells to human personality to climate, share certain principles in common by virtue of being organized groups of parts (Von Bertalanffy, 1950). General systems theory seeks to describe the universal principles of systems such as whether they are closed to their surroundings or open to their neighbors, how systems are structured, and to describe selfregulatory processes such as feedback loops (Powers, 1990; Royce \& Powell, 1981b). Almost all personality psychologists agree that personality is a system. Hall and Lindzey (1957), in their authoritative mid$20^{\text {th }}$-century review of the discipline, asked:

Who is there in psychology today who is not a proponent of the main tenets...that the whole is something other than the sum of its parts; that what happens to a part happens to the whole...Who believes that there are isolated events, insulated processes, detached functions? (Hall \& Lindzey, 1957, p. 329)

Hall and Lindzey answered their own question, concluding that all personality psychologists were systems theorists (Hall \& Lindzey, 1957, p. 329). More recently, Lawrence Pervin opined in his first Handbook of Personality Theory and Research: ...the organization of the component parts [of personality] ... is what is truly distinctive about the field, and ...recognizing this would lead to a greater emphasis in research on the system aspects of personality functioning. (Pervin, 1990, p. 12) Moreover, personality psychologists almost uniformly employ systems definitions of personality (Mayer, 2007a).

General systems theory itself, however, never became an integrative movement in personality psychology. Although the systems approach can be very helpful, it is also often abstract and unmoored from the particulars of a system under study. The limiting factor of general systems theory is that each systemfrom an atom of xenon to a human liver-is 
also unique in many ways and occupies its own context. Explaining the liver with reference to the xenon atom may well tell us something about systems in general, but it won't help us understand much about the liver or what a xenon atom is specifically like.

There is, however, one general principle that I believe is crucial to understanding most systems. To understand a system, we human beings identify the system and examine its parts, organization, and development; this is true whether we are studying an atom, an educational system, or personality itself (Mayer, 1993). Just as a young person might become fascinated by a clock and take it apart to see what's inside, we "look inside" personality to see how it works. The young person learns about the clock from its parts, how they fit together, and what the clock does over time. We use a similar approach to understanding personality by examining its parts, how the parts are organized, and their development. This approach's universality is precisely what makes this set of unifying principles for understanding personality so compelling (Mayer, 1993). Although these "learning topics" are bare bones by themselves, developing them with light touches of theory can bring the system to life.

The next four sections of the article parallel the four topics of the personality framework: the identification of personality, its parts, organization and development. As I describe these topics, I'll interweave a discussion of the theory of personal intelligence - a theory that has grown from the framework but is distinct from it. The theory of personal intelligence argues that human beings evolved an interconnected set of mental abilities for reasoning about personality in everyday life - for tracking clues to one another's personalities, forming models of personality and anticipating what people will do. I'll show how the theory of personal intelligence drew on the framework's concepts as a foundation; in fact, our everyday thinking about personality mirrors the framework in certain ways.

The article concludes with an examination of how the framework integrates key ideas in the field of personality - and a note on how we may use a unified mental ability - personal intelligence - to understand one another.

\section{Identifying the Personality System: The First Topic}

As I've already suggested, I believe that to understand personality it helps to organize our field according to four broad topics:

(a) Identifying personality by defining the system and then understanding the boundaries of personality, its expressions, and the neighboring systems with which it interacts;

(b) Cataloguing personality's parts by enumerating and defining the key parts of our mental life including our motives, traits, schemas, and other key elements;

(c) Depicting personality's organization through studying how personality is organized, including its structure and dynamics. Structure refers to the relatively long-term and enduring aspects of the system; dynamics to how the parts interact and change over time;

(d) Tracing personality development by examining the developing and changing nature of personality over time (e.g., Mayer, 1998; Mayer \& Allen, 2013).

To fully identify personality - the first topic - we must first define and locate what we hope to study.

\section{Personality's Definition and Location}


A systems definition. Wilhelm Wundt (1897) first described personality as a system - an organization of parts - and this idea is equally contemporary today across almost all textbooks and many articles in the field (Mayer, 2007a). For example, in their personality textbook, Larsen \& Buss offer: Personality is the set of psychological traits and mechanisms within the individual that are organized and relatively enduring and that influence his or her interactions with, and adaptations to, the intrapsychic, physical, and social environments (Larsen \& Buss, 2005, p. 4).

Their definition is not so different from my own:

Personality is the organized, developing system within the individual that represents the collective action of his or her motivational, emotional, cognitive, social-planning, and other psychological subsystems (Mayer, 2005, p. 296).

In fact, most textbooks employ this same systems-oriented conception, depicting personality as a global pattern, consistency, or organization of an individual's key mental qualities.

The definition of personality by itself, however, isn't enough to fully develop the first topic. The definition leaves the system "dangling in space"- unconnected to its neighboring systems of importance. But personality is very much connected to our bodies and our environments. The personality framework addresses this issue by providing a map that represents personality amidst its neighboring systems.

\section{The Positional Model: A Two Dimensional} Depiction of Personality

Figure 1 shows personality amidst its neighboring systems, arranged in two dimensions. (A third dimension represents the development of the system over time). According to this depiction, personality (middle) is "Inside the Person," emerging from the brain and other biological systems. "Outside the Person" (the right-most column) is the setting and the situation with which personality also interacts. The vertical dimension of Figure 1 orders the brain, personality, and social groups from lowest to highest along a molecular-molar continuum. Here, the framework draws on a theory of science that smaller systems (e.g., brain areas) are placed lower and larger systems such as the individual are placed above in the order they emerge from one another (Levy-Bruhl, 1903). This molecular-molar dimension is regularly used by researchers and theorists and sometimes goes by the name of the biopsychosocial continuum (Engel, 1977; Sheldon, Cheng, \& Hilpert, 2011).

The second inner-outer dimension divides the individual's personality, which is viewed as interior and emerging from the brain (to the left), from the outer physical setting and situation (to the right). The "outer systems" adjoining personality — the setting and the situation - are arranged according to their own molecular-molar relationships. Here, the term "setting" is meant to evoke a theatrical production's stage setting: the scenery, props, and costumes that help to define the character. The setting includes a person's physical location, dress and any possessions she might have with her. A given setting in our life includes the place we are, what we wear there, and any objects we use: for example, we are in our garage in work clothes using a power drill.

Emerging from the setting is a psychological situation (Figure 1, rightmiddle). The person's social situation is a psychologically-construed meaningful interaction with some aspect of the world around us, such as fixing a screen door, walking to school, shopping, or asking for a 
raise. In classical Barkerian social psychology, different situations such as "arithmetic lessons," "mealtimes," and "sports events" have specific effects upon a person's behavior (Barker, 1965, p. 10). People behave studiously at an arithmetic lesson, and behave like sports fans in a stadium, cheering their team and imbibing beer. Lastly, both the individual and the situation (including other people in it) are part of broader social groups (Figure 1, top).

Further considerations of the twodimensional model. Sheldon (2011) raised concerns that this positional model is a marked departure from the traditionally onedimensional version of the molecular-molar continuum that transits from the brain through the psychological mind to society. From his perspective, the setting and situation to the right don't appear to fit. I've argued that by using two dimensions we can clarify the specific systems with which personality interacts (Mayer \& Lang, 2011) and, for example, better distinguish situations from group membership. This does require, however, accepting the use of two strands of the molecular-molar continua in the diagram —one inside and one outside the person.

The molecular-molar continuum describes relationships in which larger systems emerge from smaller ones - but the continuum contains many separate strands that together describe our multifaceted world. A computer is molar relative to the circuitry that makes it up, but its molarity is along a strand that is distinct from that of personality and the brain. If we are at work on a desktop computer in our office, the computer is part of our outer environment - part of our external situation. The continua of brain-topersonality, on the left, and setting-tosituation, on the right, are therefore different but parallel.
Notice also that the inner-out dimension clarifies that personality — our mental life-is entirely within us. We plan any behavior we will emit in our minds and express it through our body's communication channels - the face, skin, language, hands, and other means of expression we employ to act in the outer world. Our personality therefore exists within our bodies; we are known to others through our expressive acts.

Notice also that the inner and outer portions of personality merge into social groupsa molar area they share in common. As an example, when I teach a class in psychology, my personality is within me and I express myself in the outer setting of the classroom with its students, chairs and desks. At that time, I am involved in a class meeting - a situation I share in common with my students. All these systems - my personality, the classroom setting and the situation of the class meeting - are part of the broader social organization of the University of New Hampshire.

Winter and Stuart (1995) raised concerns that this positional model might not generalize to non-Western cultures because it represents personality as relatively isolated from the family. The model is surely part of a Western intellectual tradition; with that acknowledged, personality is connected to the family both because it is a member of the more molar family group (in the 'society and culture' area), and because personality interacts with situations that for most people will include family members.

\section{A Theoretical Interpretation of the Positional Model}

This positional model also reveals something about the function of personality. The passage below - set off because of its importance - begins with ideas borrowed from evolutionary psychology and from social 
psychology and then draws on the positional model itself:

The aims of personality are to promote the survival, reproduction, and the wellbeing of the individual and, more generally, to contribute to society. To do this, personality coordinates our inner mental systems to cope with the obstacles and seize the opportunities presented by the world in which we live. We encounter these obstacles and opportunities in our physical qualities and limits and within the settings in which we find ourselves, the groups to which we belong, and in the stream of situations that we encounter over the days of our lives.

Personality, in other words, must often compromise among the demands of the multiple systems surrounding it to function as best it can.

\section{The Personality Systems Framework and the Theory of Personal Intelligence}

Each of us knows - or thinks we knowsomething about personality. We develop everyday (lay) theories of personality, form opinions of one another and try to anticipate one another's behaviors (Andersen \& Chen, 2002; Cantor \& Mischel, 1977; Plaks et al., 2009). I believe we draw on a "personal intelligence" - an intelligence about personality - to reason in this area. We use our personal intelligence to solve problems in four areas in particular: We (a) identify clues that tell us about personalities, (b) use the clues to form mental models of a given person, (c) use that personality-relevant information to guide our choices about an individual and (d) on that basis systematize our plans and goals (see Figure 2).

\section{Personal Intelligence and Clues to Personality}

To understand personality, we identify clues to who we are. The positional model just described provides a catalog of where clues to personality might be found and the theory of personal intelligence draws on it (Mayer, 2004). Clues to personality divide rather conveniently into clues from personality itself and clues from its surrounding areas: the body and brain, the setting, situation, and group memberships. Beginning with the body, we draw clues to people's personalities from their faces, where their facial configuration may indicate whether a person is agreeable or neurotic (Penton-Voak, Pound, Little, \& Perrett, 2006; Zebrowitz, 2006). We also draw clues from a person's setting: If we notice that someone's office is clean, well organized and lacks clutter we might guess - with better-thanchance accuracy - that the person is conscientious (Gosling, Ko, Mannarelli, \& Morris, 2002; Gosling, Sandy, \& Potter, 2010; Mehl, Gosling, \& Pennebaker, 2006).

We draw further clues to personality from how people act in situations: In zeroacquaintance studies, participants observe other people talk about themselves for the first time and notice visible relationship behavior such as "is cheerful," "is a talkative individual," and "tends to arouse liking and acceptance" (Funder \& Dobroth, 1987; Funder, 2001; Human \& Biesanz, 2011; Kenny, Snook, Boucher, \& Hancock, 2010).

Clues to personality are found in an individual's group membership as well. Fiske (1993, p. 162) argues that perceivers use gender, age, and ethnicity (which are physical qualities as well as signifiers of group memberships) to make sense of their social worlds (see also, Freeman \& Ambady, 2011). Better observers use information from such group memberships to enrich their 
understanding of others (Fiske, 1993; Kenny et al., 2010; Lee, McCauley, \& Jussim, 2013).

Just as we search for clues to other people, we search for clues to ourselves. One way we do this is through introspectionsome forms of which are accurate, and others less so. Introspecting into emotions is accurate almost by social definition. If I say, "I'm sad," conversational rules pretty much demand an acceptance of my claim (Gertler, 2003, p. xvi). At the same time, Dunning (2005) has explained why looking inward for evidence of our abilities is often - but not always - likely to fail, and Wilson has performed a similar service regarding preferences (Wilson, 2009).

\section{Personal Intelligence and the Ability to} Identify Information about Personality

People exhibit reliable individual differences in their ability to spot clues to personality. In one study, my colleagues and I showed test-takers pictures of dormitory bedrooms and asked them to guess the conscientiousness of the person who lived there. We also asked questions about identifying inner states - for example, test takers were asked, "If a person's mind wanders, and they feel impatient and distracted, their mental state is mostly likely?"- and then were asked to endorse the best of four alternatives including "(a) boredom" (the correct answer) and "(b) between sleep and waking." Certain tasks like this work consistently over samples but others less so (we have given up, for now, on items with visual stimuli). Among tasks that work, participants exhibit reliable individual differences in the range of $\alpha=.53$ to .61 across studies in recognizing relevant clues to personality (Mayer, Panter, \& Caruso, 2012).

\section{Parts of Personality: The Second Topic}

The second topic of the personality systems framework concerns understanding personality's parts. Broadly speaking, we infer that a part of personality exists to carry out a personality function. We infer the existence of an "emotions system" from people's emotional reactions, and infer a "cognitive system" from the ingenious ways that people think. In addition to these broad systems, we notice individual differences in how people behave - and if someone is talkative while another one is taciturn, we may infer there exists an attribute of "talkativeness" as well. By the late $20^{\text {th }}$ century, personality textbooks included more than 400 personality parts in their glossaries (Mayer, 1995). Some of the identified parts were duplicates - similar parts given different names by theorists from competing theoretical perspectives (the "jangle fallacy" Kelley, 1927). Nonetheless, personality is likely composed of a large number of parts given the number of functions the system carries out.

\section{Evolved Difference Detection}

Both the broad mental functions we carry out such as emotional and cognitive responding, and the specific ways in which those functions vary - according to our neuroticism, curiosity and imagination - are attempts to adapt to our surrounding world. Our individual differences represent tradeoffs in adaptation that we use to fill our given environmental niche. Each trait has its own costs and benefits: Conscientiousness affords us dependability, the ability to work hard, and to delay gratification - but it also entails rigidity and the possibility of failed gratification if we delay our pleasures too long (Nettle, 2006). Buss (2010) argues that, given the wide range of human variation, our ancestors evolved difference detectors to 
distinguish people's physical and mental qualities. For example, human males use cues from the voice, face and body to quickly assess the fighting ability of their male peers (Sell, Hone, \& Pound, 2012). In fact, we often judge one another in an instinctual-like way that is quick, strong and automatic (Haselton $\&$ Funder, 2006). Although it is difficult to surmise what our evolutionary ancestors thought of one another, we do know that discussions of individual differences were a part of humanity's earliest written documents. These writings appeared in diverse regions of the ancient world that had little contact with one another suggesting the universality of people's evaluations of one another (Mayer, Lin, \& Korogodsky, 2011). Today, our language includes large numbers of words to describe personality - tools for detecting and labeling personality parts. Many of these can be organized into "big traits"_-broad traits made up of more specific features; for example, extraversion can be divided into enthusiasm and assertiveness (DeYoung, Quilty, \& Peterson, 2007; Goldberg \& Rosolack, 1994).

\section{Societal Need}

We also notice personality parts out of social necessity. For groups to function successfully, their members must evaluate their peers according to whether they meet the standards of the community (Dunbar, 2009). For example, group members identify any community members who, due to illness, their environment, or for other reasons are unable to fulfill their social roles. Over history, physicians and others learned to identify traits or symptom syndromes that signaled mental illness so as to explain the relational patterns of people who had difficulty meeting social standards and who therefore required treatment, and who in earlier times were isolated, incarcerated or executed (e.g., Ellenberger, 1956; Smith, 2012). Today, clinical psychologists, psychiatrists, and professionals in related groups exert the legal authority to determine a person's relative psychological health or disease through the Diagnostic and Statistical Manual of Mental Disorders (DSM-5, 2013). These societal needs, then, are a second source that motivates the discovery and labeling of parts of personality.

\section{Expert Analysis}

Finally, psychologists identify parts of personality based on their expert knowledge of personality research and their own theoretical conceptions. Kosslyn and colleagues (2011) conducted a meta-analysis of areas of the brain and their functionality and concluded that the upper portions of the human cerebral hemisphere carry out holistic, abstract thinking and make generalizations, whereas the lower portions are dedicated to understanding specific instances of events in individual contexts (Borst et al., 2011; Kosslyn \& Miller, 2013). They reasoned that different people exhibited individual differences in their preferences for holistic versus specific thinking, and differentially drew on the upper or lower portions of their hemispheres in the process. Recently, they have used this model to create an integrative treatment of human cognitive styles that draws on conceptions from education, psychology and organizational behavior (Kozhevnikov, Evans, \& Kosslyn, 2014).

Many other expert-identified traits help to explain personality including repressionproneness (as a personality trait), internalversus-external locus of control, and time perspective, which involves a focus on the past, present, or future. Experts also have developed the concepts of psychological absorption, an altered state of consciousness related to flow and hypnotic ability, general intelligence (a part of personality as identified here) and action identification, which concerns whether a person views acts as integrated and goal-directed-as in the case 
of "making a good impression"- - or as more concrete and specific, as in "smiling a lot" (Hölzel \& Ott, 2006; Keough, Zimbardo, \& Boyd, 1999; Kremen \& Block, 2002; Vallacher \& Wegner, 2000; Weinberger, Schwartz, \& Davidson, 1979; Zimbardo \& Boyd, 1999).

These and other expert-identified traits are as predictively valid as those found within the Big Five. Some examples: Internalexternal locus of control predicts job satisfaction, performance at work, and overall well-being ( $\mathrm{Ng}$, Sorensen, \& Eby, 2006; Twenge, Zhang, \& Im, 2004; Wang, Bowling, $\&$ Eschleman, 2010). General intelligence correlates $r=.8$ with scores on national tests of educational achievement, and it predicts job performance, occupational attainment and social mobility (Deary, Penke, \& Johnson, 2010; Nisbett et al., 2012). People who are "high" in action identification, conceiving of their acts at a purposive level, are more effective at self-presentation and at understanding other people's acts than those who identify their behaviors more concretely (Kozak, Marsh, \& Wegner, 2006; Vallacher \& Wegner, 1989; Vallacher \& Wegner, 2000).

\section{Personality Parts beyond Traits}

Other parts of personality aside from traits are crucial to our mental functioning. We construct schemas of other people to classify them, scripts for how they behave, and stories of their lives (McAdams, 1996). For example, we construct schemas of significant people we have known and then may generalize a schema (and its features) to a new person we meet (Andersen \& Chen, 2002). We may often revise and refine these memory structures if we realize a new person is different from an earlier individual in our life (Mayer, 2014a). The more accurately we can recognize and label parts of personality, use our schemas, and apply accurate models, the more we know about people (including about ourselves).

\section{Personal Intelligence and Forming Models of Individuals}

We use our personal intelligence to label personality's parts and that helps us understand their intentions. For example, if I know a person who is extraverted, and he invites me to go with him to a party, I will interpret the invitation in light of his natural desire for company rather than as a particular interest he might have in forming a closer relationship with me. By comparison, if an introvert were to ask me to a party, the invitation would take on more significance because I know that introverted people aim toward the more gradual development of a friendship and are more selective about the company they keep (Nelson \& Thorne, 2012). The theory of personal intelligence predicts that some people will be better than others at noticing and labeling parts and anticipating people's behaviors on that basis.

Christiansen et al. (2005) assessed people's understanding in this area by asking study participants to identify traits that go together. A sample test item read:

Coworkers who tend to express skepticism and cynicism are also likely to

A. Have difficulty imagining things

B. Get upset easily

C. Dominate most interactions

D. Exhibit condescending behavior (Christiansen et al., 2005, p. 148). The correct answer was "D. Exhibit condescending behavior." After taking the test, the participants watched a video of a job applicant and estimated his characteristics. People who scored higher on the traitknowledge test did a better job of estimating the applicant's self-description.

The Test of Personal Intelligence I've developed with my colleagues includes similar questions about traits. Participants show reliable individual differences in 
accurately labeling and describing traits (which is part of the "forming models" area), ranging from $\alpha=.67$ to .76 across three initial studies. Scores on the forming models tasks also correlated with the earlier-described identifying-clues items about $r=.49$ to .59 . The breadth of problem-solving - spanning both identifying clues and labeling traitsstrengthens the idea that this is a broad intelligence (Mayer et al., 2012). But of course there is more to forming models than just traits - and even if there weren't, it helps to place traits into some kind of organized system so as understand their relationships to one another and to keep track of the many possible parts of personality that exist.

\section{Personality Organization: The Third Topic}

\section{Personality Structure and Dynamics}

The third topic of the personality systems framework is "personality organization," including personality's structure and dynamics. Personality structure refers to the relatively long-term and stable aspects of a person's mental functioning. Certain structural models divide personality into areas based on the functions they carry out (e.g., emotions versus cognition); other structures divide the system into groups of big traits such as the Big Five. Personality structure is often depicted in terms of map-like diagrams: think historically of Freud's sketch of the id, ego, and superego, or of the hierarchicallyorganized diagrams of the Big Five. Different structural models of personality are useful for different purposes. As an analogy, think of city maps: A transit map of the greater Los Angeles area reveals useful information, although it's different from the information depicted in a map of the "homes of the Hollywood stars." And of course, maps (and structural models) can be more or less accurate.

\section{The Functional Approach to Structures}

Examples of structural divisions of the mind range from the historically important division among motives, emotions and cognition (Hilgard, 1980) and Freud's (1961) id, ego, and superego, to the contemporary division by Kosslyn and Miller (2013) of the mind into upper and lower functions of the cerebral hemisphere. A review of the major models of personality structure suggests that philosophers and psychologists implicitly follow several criteria when they divide up the mental processes of personality: they (a) employ a small number of areas that typically range from 2 to 7 , (b) ensure that the areas are relatively distinct from one another, and (c) join together areas that comprehensively cover the personality system (Mayer, 2001; Mayer, 2005).

The "areas" of structural models vary substantially. Some models emphasize broad classes of mental functions such as the emotion system that appraises situations and responds with feelings, and the cognitive system; quite different models include agentic entities such as Freud's "id" and "ego" that act in partial independence of one another. Other models focus on neurological structures of the brain such as the "reptilian" and "oldmammalian" brains that follow their own sets of rules of information processing (Freud, 1961; Hilgard, 1980; MacLean, 1973). Another group of models examine "big" traits such as such as extraversion that are superordinate to more specific, highly correlated traits such as surgency and sociability (Goldberg \& Rosolack, 1994); these trait-based models are more centrally focused on patterns of individual differences than functional models and they organize traits together based on their correlations across people. 
The personality systems framework also maps the structural organization of personality, dividing the system into four functional areas called the systems set: (a) energy development, (b) knowledge guidance, (c) action implementation, and (d) executive management. These are arranged in Figure 3 according to the earlier-described molecularmolar and inner-outer dimensions, with energy development relatively molecular and inner, and action implementation relatively outer and mid-level along the molecularmolar continuum (Mayer, 2003; Mayer, 2005; Mayer \& Korogodsky, 2011). Energy development includes motives and emotions that are grouped together based on their close interactions. For example, if we are motivated to seek companionship, positive emotions may facilitate our sociability; negative emotions may dampen our effectiveness (Gable, Reis, \& Elliot, 2000; Pickering \& Gray, 1999). Emotions also guide the expression of our needs in the surrounding world: our liveliness will steer us towards social outlets; our guilt will signal whether we owe someone an apology. The second area, knowledge guidance, includes our knowledge and the intelligences we use to reason about what we know. Action implementation describes the plans we develop to carry out behaviors in the situations we face. Finally, executive management concerns how an individual monitors and guides herself over time. Some self-management is automatic and non-conscious, but over time a person creates increasingly powerful representations of her personality, allowing for better control and modulation of her behavior.

\section{Research Support for the Systems Set}

Barlow and I found support for the systems set when we asked participants to sort personality functions into multiple categories. When we applied multidimensional scaling to their categorizations, we found that participants regularly employed molecular- molar and inner-outer dimensions, in essence reproducing the systems set (Barlow \& Mayer, 2014). Expert judges also evaluated the systems set areas as both distinct from one another and comprehensive in covering the personality system, relative to such alternative divisions as the trilogy of mind (motivationemotion-cognition) and Freud's id, ego, and superego (Mayer, 2001). In another study, nine graduate student judges sorted approximately 70 psychological traits into the four areas of the system set, and, for the sake of comparison, also into the three categories of the trilogy-of-mind. The four areas of the systems set are also relatively distinct from one another, as indicated by the ability of the graduate students to agree on which traits applied to which areas - the judge's level of agreement was highest when using this fourfold division relative to other approaches. The panel also reflected the comprehensive coverage of the systems set: They were able to sort $98.7 \%$ of the relevant traits in the four areas; the same panel achieved only an $87.3 \%$ classification rate with the next-best division of the trilogy of mind (Mayer, 2003).

Psychologists can use the results from such studies to superimpose traits on the functional areas (and blends of areas) the traits describe. In Figure 3, achievement needs, positive affect and negative affect (neuroticism) all describe the nature of a person's energy development (Figure 3, bottom left); intellectual traits including general intelligence, openness to experience and curiosity are relevant to the knowledge guidance area (Figure 3, top left); politeness and attachment styles describe action implementation (Figure 3, right); and selfmonitoring and conscientiousness describe executive self-management (Figure 3, top).

This depiction of personality rests on the aforementioned theoretical precepts of how to divide personality functionally, as well as a view of traits as describing personality 
function (Averill, 1992; A. H. Buss \& Finn, 1987; Mayer, 2005).

A note on the correlational approach to organizing traits. The systems framework approach is a big tent and other models of personality structure also inform our ideas of personality structure in important ways. Central among these are structural models based on trait correlations. The widely used "big trait" approaches such as Eysenck's Big Three, the Big Five and the Big Six, are alternative structural models along a common vein. Designating a general trait term as an umbrella concept for a correlated group of specific traits, they integrate more specific traits within the general concept (Ashton \& Lee, 2010; Zuckerman, Kuhlman, Joireman, Teta, \& Kraft, 1993). For example, the big trait of conscientious breaks down into facets of industriousness and orderliness (DeYoung et al., 2007). Another such model is the Cattell-Horn-Carroll model of intelligence, with " $\mathrm{g}$ " at the top and broad intelligences such as verbal, spatial and mechanical — and, I believe, personal intelligence-forming its facets (Mayer, 2014a; McGrew, 2009).

\section{Personality Dynamics Tell Us How the} Parts Work Together

In addition to structure, personality organization also concerns personality dynamics; these involve the active processes that determine how personality is expressed. Dynamics can be defined as the way in which parts and areas of personality work together to create outcomes. Under the banner of dynamics are diverse topics: Some small dynamics concern just how two traits interact or the expression of a trait in a particular context (Orom \& Cervone, 2009). Other dynamics are global and cross many parts of the personality system.

We can glean what are probably two top-level dynamics of personality by referring back to the diagram of personality structure in Figure 3. The first of these reaches from energy development to action planning; in essence it describes how we go from our inner needs to functioning in our outer environment. These are labeled "Dynamics of Action" in Figure 3.

Henry Murray's foundational work on motives examined these dynamics: from a person's "rhythms of activity and rest" to how a person's needs are eventually satisfied (Murray, 1938, pp. 38-42). Psychologists continue to study the effect of needs on outer behavior today using new approaches to identify basic motives (Reiss, 2004), explaining how basic needs are expressed at work and regulated through self-control (Lanaj, Chang, \& Johnson, 2012; Latham \& Pinder, 2005) and more broadly, how motives are expressed in interpersonal contexts (Horowitz et al., 2006). The expression of behavior - from motives to action - is, of course, mediated by our models of the world as well as by the actual outer environment, which affects our wants, desires and aspirations, as well as how we self regulate.

The second group of these global dynamics is the "Dynamics of Self Control" (Figure 3, top middle); these dynamics originate with executive management and act on the other personality systems. Executive management guides and controls the rest of personality; the rest of personality may follow along or resist such control in return. Selfregulation research often examines automatic homeostatic self-regulation. Carver and Scheier (1982) elaborated a theory of control centered on the emotions drawing on a systems theory from Powers $(1973 ; 1990)$. But we also engage in self-control and defense by using coping and defense strategies (Cheng, Lau, \& Chan, 2014; DeSteno, Gross, \& Kubzansky, 2013; Helgeson, Reynolds, \& Tomich, 2006; Skinner \& Brewer, 2004). In addition, we may employ a possible third line of "intelligent" self-regulation related to 
personal intelligence and intelligence more broadly (Mayer, Panter, \& Caruso, 2014).

\section{Personal Intelligence: Guiding Choices}

Personal intelligence describes how people reason about themselves and other people. When we "form models" of personality (the second area of reasoning) we draw not only on one trait at a time to describe a person, but consider groups of traits and their interactions in gauging what someone is like — evaluating not only a person's warmth but the individual's competence; not only his intelligence but also his conscientiousness.

Personal intelligence's third area of reasoning involves using personality-related information to guide one's choices. In the Test of Personal Intelligence, the "guiding choices" area contains questions about how people motivate themselves and how they plan to meet goals. For example, if a person wants to become good at the violin, we ask, "how could she think or act to attain her goal?" This involves reasoning about how to draw on the right parts of oneself to meet an objective. In the "good violinist" example, alternatives include to think of oneself (a) as happily married with a stable family, or (b) to carry through on practicing violin each day (the better answer). In another set of items of this type, we ask people to identify personal memories that might motivate them to attain a goal-for example, an athlete might recall being cut from a junior varsity team to motivate herself to practice the sport harder (e.g., Pillemer, 2003). The "guiding choices" items distinguish among participants who are good versus poor at reasoning in the area with a reliability of $\alpha=.81$ to 84 . Reasoning in the area correlates moderately with problemsolving in the earlier areas studied (identifying clues and forming models); the correlations range from $r=.36$ to .80 depending upon the specific scale and sample (Mayer et al., 2012). Once again this is consistent with the pattern we'd expect for a broad intelligence concerned with reasoning about personality.

\section{Development of Personality: The Fourth Topic}

\section{Overview of Development}

The fourth topic of the personality systems framework concerns development of the system over time. As a person grows, the settings, situations and groups she encounters change from early childhood relations at home and school to adult encounters, perhaps in a newly-formed family or in the workplace. The development topic includes research from the work of Levinson, Helson and others on adult personality development, life-history theory, the contributions of key traits such as intelligence and conscientiousness and their contributions to occupational achievement, health and longevity over time (Caspi, Roberts, \& Shiner, 2005; Luyten \& Blatt, 2013; McAdams \& Pals, 2006; Rothbart, 2007; Torges, Stewart, \& Duncan, 2008). The parts of an individual's personality also change over time, becoming more differentiated from childhood to adulthood and then changing in response to the person's environment (Rothbart, 2007). People can be viewed either as passing through stages in which they undergo qualitatively discrete transitions (e.g., Erikson, 1950; Levinson, 1986), or as experiencing more gradual rises or declines in individual traits (e.g., Roberts \& Mroczek, 2008). Finally, personality organization - most usually dynamics - can change as an individual tries new ways of behaving and exercises new coping strategies over his life (McAdams \& Olson, 2010; Rothbart, 2007; Torges et al., 2008). 
Personal Intelligence, the Systematization of Life Goals, and Further Comments on the Test of Personal Intelligence Systematizing life goals and plans.

The final area of problem solving with personal intelligence involves systematizing one's goals and plans. For example, people vary both in how well they formulate goals that work well together, as well as the memories they draw on to motivate themselves (Emmons \& King, 1988; Pillemer, 2003; Sheldon \& Kasser, 1995).

The Test of Personal Intelligence assesses whether people can distinguish between goals that are attainable such as making a new friend versus goals that are more problematic such as "to be all things to all people" (Emmons \& King, 1988). Once again, people vary reliably in their abilities to recognize problematic goals; the goal-related scales exhibit reliabilities varying from $\alpha=$ .65 to .75 across samples. Abilities in this area also correlate with performance on the earlier sets of items I've described of between $r=.36$ and .73 across studies (Mayer et al., 2012).

Concluding comments on the TOPI. Since our 2012 publication describing the Test of Personal Intelligence, my colleagues and I have administered versions of the test to two additional samples. In these new samples, five item clusters dropped in reliability to a point where we removed them (including all the visual "identifying clues" items). The revised TOPI 1.4 now consists of 13 item sets. The full-scale test scores range in their reliabilities from $\alpha=.84$ to .93 across samples. In all the studies, personal intelligence shows evidence of being a unitary ability with two highly correlated subfactors representing, first, the ability to describe personality and, second, the ability to reason with the descriptive information (Mayer et al., 2014).
People high in personal intelligence are able to solve a broad array of problems having to do with personality. The Test of Personal Intelligence shows further evidence that it measures a broad intelligence: TOPI scores correlate with vocabulary knowledge (a frequent stand-in for verbal intelligence), with $r$ 's $=.39$ to .45 across samples suggesting it is related to other intelligences but also distinct from them (Mayer et al., 2012). Intelligences often correlate with openness to experience as well and the TOPI shows a similar though weaker pattern with openness, with $r$ 's $=.16,-.02$ and .11 across samples ( $\mathrm{p}<.05 ;$ n.s.; $\mathrm{p}<.05$, respectively).

\section{Discussion and Conclusions}

\section{Revisiting Systems Thinking}

General systems thinking has a mixed track record in personality psychology. Scientists from outside the discipline who have applied it to personality often generated ideas that were abstract and insufficiently developed to make contact good with the field. Von Bertalanffy, a biologist by training, enumerated several principles of personality in the Journal of Personality. He began with the idea that "A living organism is a hierarchy of open systems maintaining itself in a steady state..." (Von Bertalanffy, 1951, p. 37). He argued there were neurological, paleo-brain and cognitive brain levels of personality much like MacLean's (1973) three brains, and that goal seeking and true purposiveness were essential elements of being human. I think most of us would agree with Von Bertalanffy's observations but also appreciate how little they add to current attempts at addressing what personality is and how it functions. Royce and Powell (1981a; 1981b), professors at the University of Alberta's Center for Advance Study in Theoretical Psychology, published three systems-inspired articles in the Journal of Personality and 
Social Psychology in a similarly abstract vein. Perhaps these systems approaches to personality appear superfluous at times because personality psychologists are by nature systems thinkers (see Fajkowska, 2013, this issue). But sometimes general systems theory can be helpful. The basis for the personality systems framework is the idea that in addition to regularities in systems, there also are regularities in how we describe systems.

\section{The Systems Framework Organizes what Personality Psychologists Do}

The personality systems framework is enriched by its borrowings from general systems theory, the theory of science (e.g., molecular-molar continuua), evolutionary and sociological theory, and reviews of structural models of personality. The framework depicts personality and provides a clear indication of what personality does: Personality negotiates between inner needs and resources and outer demands so as to survive and thrive. In picturing personality, the framework also organizes contemporary research in the discipline. In Table 1, "Five Focal Areas in Personality Research" I've laid out one possible organization of research foci in the field today as developed in textbooks, in meetings of the Association for Research in Personality, and of related associations. As a further check as to the completeness of the account, I studied the websites of personality laboratories at diverse colleges and universities and read through the activities in which they were engaged.

The focal research areas begin with one of the key enterprises of the fieldlooking at how we understand and perceive one another (Table 1, $1^{\text {st }}$ focus). Much of our research begins with interpersonal perceptions and noticing, for example, the parts of personality. Accompanying that perceiving is the research-based identification of key personality parts ( $2^{\text {nd }}$ focus $)$ and how they fit together ( $3^{\text {rd }}$ focus). As personality parts become better understood, researchers examine how such parts combine to create better models of personality and what combinations of parts and their dynamic interactions predict ( $4^{\text {th }}$ focus), as well as how they develop over time ( $5^{\text {th }}$ focus $)$. For each area, I've listed the key goal of the specific research area as I understood it, along with a general characterization of the primary methods used to study the topic, and specific examples of research being conducted.

These five areas roughly correspond to the personality systems topics themselves. The first focus - understanding how we perceive personality - is loosely tied to identifying and defining personality. The second focus, identifying personality parts corresponds to the "parts of personality" topic. The third focus concerns studying sets of parts and corresponds to personality structure. The fourth focus, "understanding how the parts work together" speaks to the dynamics of personality. And the fifth focal area concerns personality development. To the degree Table 1 fairly represents research work in the field, it could be regarded as further evidence of the utility of the personality systems framework.

\section{Personal Intelligence Employs the} Framework

The personality systems framework-in the sense of an "outline for the field"-is lightly influenced by theories and it provides a firm foundation for the development of theories about how personality functions. Personal intelligence is one such specific theory that describes how people make sense of personality - both their own and others'. The theory plainly draws on the positional model of the personality systems framework to specify from where we draw clues to personality. Personal intelligence is a part personality that fits within the intelligence area. As an intelligence, it contributes 
dynamically to self-management and selfguidance.

The theory of personal intelligence speaks to the integration of the discipline in a rather different way than does the personality systems framework. Research findings indicate that people who can problem-solve in one area of personality (e.g., recognizing clues) are good at solving problems in the other areas as well (e.g., forming models, systematizing plans and goals). Such findings suggest that a previously unidentified but naturally-arising broad intelligence is at play in our everyday understanding of personality. By comparison, the personality systems framework draws on the discipline of personality psychology to provide a more formal vision of who we are. Both approaches help us to better understand and navigate our peopled world. 


\section{References}

Andersen, S. M., \& Chen, S. (2002). The relational self: An interpersonal social-cognitive theory. Psychological Review, 109(4), 619-645. doi:10.1037/0033-295X.109.4.619

Ashton, M. C., \& Lee, K. (2010). Trait and source factors in HEXACO-PI-R self- and observer reports. European Journal of Personality, 24(3), 278-289. doi:10.1002/per.759

Averill, J. R. (1992). The structural bases of emotional behavior: A metatheoretical analysis. In M. S. Clark (Ed.), Emotion. (pp. 1-24). Thousand Oaks, CA US: Sage Publications, Inc.

Barker, R. G. (1965). Explorations in ecological psychology. American Psychologist, 20(1), 1-14. doi: $10.1037 / \mathrm{h} 0021697$

Barlow, B. A., \& Mayer, J. D. (2014). Mapping the mind: How people perceive and organize the major functions of personality. Unpublished manuscript.

Borst, G., Thompson, W. L., \& Kosslyn, S. M. (2011). Understanding the dorsal and ventral systems of the human cerebral cortex: Beyond dichotomies. American Psychologist, 66(7), 624-632. doi:10.1037/a0024038; 10.1037/a0024038.supp (Supplemental)

Buss, D. M. (2010). Personality and the adaptive landscape: The role of individual differences in creating and solving social adaptive problems. In D. M. Buss, \& P. H. Hawley (Eds.), The evolution of personality and individual differences (pp. 29-58). New York: Oxford University Press.

Buss, A. H., \& Finn, S. E. (1987). Classification of personality traits. Journal of Personality and Social Psychology, 52(2), 432-444.

Cantor, N., \& Mischel, W. (1977). Traits as prototypes: Effects on recognition memory. Journal of Personality and Social Psychology, 35(1), 38-48. doi:10.1037/0022-3514.35.1.38

Carver, C. S., \& Scheier, M. F. (1982). Control theory: A useful conceptual framework for personalitysocial, clinical, and health psychology.

Psychological Bulletin, 92(1), 111-135. doi:10.1037/0033-2909.92.1.111

Caspi, A., Roberts, B. W., \& Shiner, R. L. (2005). Personality development: Stability and change. Annual Review of Psychology, 56, 453-484. doi:10.1146/annurev.psych.55.090902.141913

Cheng, C., Lau, H. B., \& Chan, M. S. (2014). Coping flexibility and psychological adjustment to stressful life changes: A meta-analytic review. Psychological Bulletin, 140(6), 1582-1607.

Christiansen, N. D., Wolcott-Burnam, S., Janovics, J. E., Burns, G. N., \& Quirk, S. W. (2005). The good judge revisited: Individual differences in the accuracy of personality judgments. Human Performance, 18(2), 123-149. doi:10.1207/s15327043hup1802_2

Deary, I. J., Penke, L., \& Johnson, W. (2010). The neuroscience of human intelligence differences. Nature Reviews Neuroscience, 11(3), 201-211.

DeSteno, D., Gross, J. J., \& Kubzansky, L. (2013). Affective science and health: The importance of emotion and emotion regulation. Health Psychology, 32(5), 474-486.

DeYoung, C. G., Quilty, L. C., \& Peterson, J. B. (2007). Between facets and domains: 10 aspects of the big five. Journal of Personality and Social Psychology, 93(5), 880-896. doi:10.1037/00223514.93.5.880

Diagnostic and statistical manual of mental disorders: DSM-5 ${ }^{\text {TM }}$ (5th ed.) (2013). . Arlington, VA US: American Psychiatric Publishing, Inc.

Dunbar, R. I. M. (2009). The social brain hypothesis and its implications for social evolution. Annals of Human Biology, 36(5), 562-572. doi:10.1080/03014460902960289

Dunning, D. (2005). Self-insight: Roadblocks and detours on the path to knowing thyself. New York, NY US: Psychology Press.

Ellenberger, H. (1956). The ancestry of dynamic psychotherapy. Bulletin of the Menninger Clinic, 20, 288-299.

Emmons, R. A., \& King, L. A. (1988). Conflict among personal strivings: Immediate and long-term implications for psychological and physical wellbeing. Journal of Personality and Social Psychology, 54(6), 1040-1048. doi:10.1037/00223514.54.6.1040

Engel, G. L. (1977). The need for a new medical model: A challenge for biomedicine. Science, 196(4286), 129-136. doi:10.1126/science. 847460

Erikson, E. H. (1950). Childhood and society. New York: W. W. Norton.

Fajkowska, M. (2013). Personality coherence and incoherence. Clinton Corners, NY: Eliot Werner Publications.

Fiske, S. T. (1993). Social cognition and social perception. Annual Review of Psychology, 44, 155-194. doi:10.1146/annurev.ps.44.020193.001103 
Freeman, J. B., \& Ambady, N. (2011). A dynamic interactive theory of person construal. Psychological Review, 118(2), 247-279. doi:10.1037/a0022327

Freud, S. (1961). The ego and the id. New York, NY US: W W Norton \& Co.

Funder, D. C. (2001). Accuracy in personality judgment: Research and theory concerning an obvious question. In R. Hogan (Ed.), Personality psychology in the workplace. (pp. 121-140). Washington, DC US: American Psychological Association. doi:10.1037/10434-005

Funder, D. C., \& Dobroth, K. M. (1987). Differences between traits: Properties associated with interjudge agreement. Journal of Personality and Social Psychology, 52(2), 409-418. doi:10.1037/0022-3514.52.2.409

Gable, S. L., Reis, H. T., \& Elliot, A. J. (2000). Behavioral activation and inhibition in everyday life. Journal of Personality and Social Psychology, 78(6), 1135-1149.

Gertler, B. (2003). Philosophical issues about selfknowledge. In B. Gertler (Ed.), Privileged access: Philosophical accounts of self-knowledge (pp. xi-xxii). Burlington, VT: Ashgate Publishers Ltd.

Goldberg, L. R., \& Rosolack, T. K. (1994). The big five factor structure as an integrative framework: An empirical comparison with eysenck's P-E-N model. In R. P. Martin (Ed.), The developing structure of temperament and personality from infancy to adulthood. (pp. 7-35). Hillsdale, NJ England: Lawrence Erlbaum Associates, Inc.

Gosling, S. D., Ko, S. J., Mannarelli, T., \& Morris, M. E. (2002). A room with a cue: Personality judgments based on offices and bedrooms. Journal of Personality and Social Psychology, 82(3), 379-398. doi:10.1037/0022-3514.82.3.379

Gosling, S. D., Sandy, C. J., \& Potter, J. (2010). Personalities of self-identified 'dog people' and 'cat people.'. Anthrozoös, 23(3), 213-222. doi:10.2752/175303710X12750451258850

Hall, C. S., \& Lindzey, G. (1957). Theories of personality. New York: John Wiley \& Sons.

Haselton, M. G., \& Funder, D. C. (2006). The evolution of accuracy and bias in social judgment. In D. T. Kenrick (Ed.), Evolution and social psychology. (pp. 15-37). Madison, CT US: Psychosocial Press.

Helgeson, V. S., Reynolds, K. A., \& Tomich, P. L. (2006). A meta-analytic review of benefit finding and growth. Journal of Consulting and Clinical Psychology, 74(5), 797-816. doi:10.1037/0022006X.74.5.797
Hilgard, E. R. (1980). The trilogy of mind: Cognition, affection, and conation. Journal of the History of the Behavioral Sciences, 16(2), 107-117.

Hölzel, B., \& Ott, U. (2006). Relationships between meditation depth, absorption, meditation practice, and mindfulness: A latent variable approach. Journal of Transpersonal Psychology, 38(2), 179-199.

Horowitz, L. M., Wilson, K. R., Turan, B., Zolotsev, P., Constantino, M. J., \& Henderson, L. (2006). How interpersonal motives clarify the meaning of interpersonal behavior: A revised circumplex model. Personality and Social Psychology Review, 10(1), 67-86.

Human, L. J., \& Biesanz, J. C. (2011). Target adjustment and self-other agreement: Utilizing trait observability to disentangle judgeability and self-knowledge. Journal of Personality and Social Psychology, 101(1), 202-216. doi:10.1037/a0023782

Kelley, T. L. (1927). Interpretation of educational measurements. Yonkers, NY: World.

Kenny, D. A., Snook, A., Boucher, E. M., \& Hancock, J. T. (2010). Interpersonal sensitivity, status, and stereotype accuracy. Psychological Science, 21(12), 1735-1739.

Keough, K. A., Zimbardo, P. G., \& Boyd, J. N. (1999). Who's smoking, drinking, and using drugs? time perspective as a predictor of substance use. Basic and Applied Social Psychology, 21(2), 149-164. doi:10.1207/15324839951036498

Kosslyn, S., \& Miller, G. W. (2013). Top brain, bottom brain: Surprising insights into how you think. New York: Simon and Schuster.

Kozak, M. N., Marsh, A. A., \& Wegner, D. M. (2006). What do i think you're doing? action identification and mind attribution. Journal of Personality and Social Psychology, 90(4), 543555. doi:10.1037/0022-3514.90.4.543

Kozhevnikov, M., Evans, C., \& Kosslyn, S. M. (2014). Cognitive style as environmentally sensitive individual differences in cognition: A modern synthesis and applications in education, business, and management. Psychological Science in the Public Interest, 15(1), 3-33.

Kremen, A. M., \& Block, J. (2002). Absorption: Construct explication by Q-sort assessments of personality. Journal of Research in Personality, 36(3), 252-259. doi:10.1006/jrpe.2001.2344

Lanaj, K., Chang, C. “, \& Johnson, R. E. (2012). Regulatory focus and work-related outcomes: A review and meta-analysis. Psychological Bulletin, 138(5), 998-1034. 
Latham, G. P., \& Pinder, C. C. (2005). Work motivation theory and research at the dawn of the twenty-first century. Annual Review of Psychology, 56, 485-516.

Lee, Y., McCauley, C., \& Jussim, L. (2013). Stereotypes as valid categories of knowledge and human perceptions of group differences. Social and Personality Psychology Compass, 7(7), 470486.

Levinson, D. J. (1986). A conception of adult development. American Psychologist, 41(1), 313.

Levy-Bruhl, L. (1903). The philosophy of august comte. London: Swan Sonnenschein.

Luyten, P., \& Blatt, S. J. (2013). Interpersonal relatedness and self-definition in normal and disrupted personality development: Retrospect and prospect. American Psychologist, 68(3), 172183. doi:10.1037/a0032243

MacLean, P. D. (1973). A triune concept of the brain and behaviour: Hincks memorial lectures. Oxford England: U. Toronto Press.

Mayer, J. D. (1993). A system-topics framework for the study of personality. Imagination, Cognition and Personality, 13(2), 99-123. doi:10.2190/0B5Y-6M4L-7939-FJD8

Mayer, J. D. (1995). A framework for the classification of personality components. Journal of Personality, 63(4), 819-878. doi:10.1111/14676494.ep9512221953

Mayer, J. D. (1998). A systems framework for the field of personality. Psychological Inquiry, 9(2), 118144. doi:10.1207/s15327965pli0902_10

Mayer, J. D. (2001). Primary divisions of personality and their scientific contributions: From the trilogy-of-mind to the systems set. Journal for the Theory of Social Behaviour, 31(4), 449.

Mayer, J. D. (2003). Structural divisions of personality and the classification of traits. Review of General Psychology, 7(4), 381-401. doi:10.1037/10892680.7.4.381

Mayer, J. D. (2004). A classification system for the data of personality psychology and adjoining fields. Review of General Psychology, 8(3), 208219. doi:10.1037/1089-2680.8.3.208

Mayer, J. D. (2005). A tale of two visions: Can a new view of personality help integrate psychology? American Psychologist, 60(4), 294-307. doi:10.1037/0003-066X.60.4.294

Mayer, J. D. (2007a). Asserting the definition of personality. P: The Online Newsletter for Personality Science, 1(1), 8 June 2012.

Mayer, J. D. (2007b). Personality: A systems approach. New York: Pearson Educational.
Mayer, J. D. (2014a). Personal intelligence: The power of personality and how it shapes our lives. New York: Scientific American / Farrar Strauss \& Giroux.

Mayer, J. D. (2014b). Personality: A systems approach (edition 1.5). Durham, NH: Rubber Duck Publishing.

Mayer, J. D., \& Allen, J. L. (2013). A personality framework for the unification of psychology. Review of General Psychology, 17(2), 196-202. doi: $10.1037 / \mathrm{a} 0032934$

Mayer, J. D., \& Korogodsky, M. (2011). A really big picture of personality. Social and Personality Psychology Compass, 5, 104-117. doi:10.1111/j.1751-9004.2010.00336.x

Mayer, J. D., \& Lang, J. L. (2011). A threedimensional view of personality. Psychological Inquiry, 22(1), 36-39. doi:10.1080/1047840X.2011.544635

Mayer, J. D., Lin, S. C., \& Korogodsky, M. (2011). Exploring the universality of personality judgments: Evidence from the great transformation (1000 BCE-200 BCE). Review of General Psychology, 15, 65-76. doi:10.1037/a0020711

Mayer, J. D., Panter, A. T., \& Caruso, D. R. (2012). Does personal intelligence exist? evidence from a new ability-based measure. Journal of Personality Assessment, 94, 124-140. doi:10.1080/00223891.2011.646108

Mayer, J. D., Panter, A. T., \& Caruso, D. R. (2014). Test of personal intelligence (TOPI 1.4) manual. (). Durham, NH: University of New Hampshire.

McAdams, D. P. (1996). Personality, modernity, and the storied self: A contemporary framework for studying persons. Psychological Inquiry, 7(4), 295-321. doi:10.1207/s15327965pli0704_1

McAdams, D. P., \& Olson, B. D. (2010). Personality development: Continuity and change over the life course. Annual Review of Psychology, 61, 517542. doi:10.1146/annurev.psych.093008.100507

McAdams, D. P., \& Pals, J. L. (2006). A new big five: Fundamental principles for an integrative science of personality. American Psychologist, 61(3), 204-217. doi:10.1037/0003-066X.61.3.204

McGrew, K. S. (2009). CHC theory and the human cognitive abilities project: Standing on the shoulders of the giants of psychometric intelligence research. Intelligence, 37(1), 1-10. doi:10.1016/j.intell.2008.08.004

Mehl, M. R., Gosling, S. D., \& Pennebaker, J. W. (2006). Personality in its natural habitat: Manifestations and implicit folk theories of personality in daily life. Journal of Personality 
and Social Psychology, 90(5), 862-877. doi:10.1037/0022-3514.90.5.862

Murray, H. A. (1938). Explorations in personality: A clinical and experimental study of fifty men of college age. Oxford England: Oxford Univ. Press.

Nelson, P. A., \& Thorne, A. (2012). Personality and metaphor use: How extraverted and introverted young adults experience becoming friends. European Journal of Personality, 26(6), 600-612.

Nettle, D. (2006). The evolution of personality variation in humans and other animals. American Psychologist, 61(6), 622-631.

Ng, T. W. H., Sorensen, K. L., \& Eby, L. T. (2006). Locus of control at work: A meta-analysis. Journal of Organizational Behavior, 27(8), 10571087. doi:10.1002/job.416

Nisbett, R. E., Aronson, J., Blair, C., Dickens, W., Flynn, J., Halpern, D. F., \& Turkheimer, E. (2012). Intelligence: New findings and theoretical developments. American Psychologist, 67(2), 130-159. doi:10.1037/a0026699

Orom, H., \& Cervone, D. (2009). Personality dynamics, meaning, and idiosyncrasy: Identifying cross-situational coherence by assessing personality architecture. Journal of Research in Personality, 43(2), 228-240. doi:10.1016/j.jrp.2009.01.015

Penton-Voak, I., Pound, N., Little, A. C., \& Perrett, D. I. (2006). Personality judgments from natural and composite facial images: More evidence for a 'kernel of truth' in social perception. Social Cognition, 24(5), 607-640. doi:10.1521/soco.2006.24.5.607

Pervin, L. A. (Ed.). (1990). Handbook of personality: Theory and research. New York: Guilford.

Pickering, A. D., \& Gray, J. A. (1999). The neuroscience of personality. In L. A. Pervin, \& O. P. John (Eds.), (pp. 277-299). New York, NY, US: Guilford Press.

Pillemer, D. B. (2003). Directive functions of autobiographical memory: The guiding power of the specific episode. Memory, 11(2), 193-202. doi:10.1080/741938208

Plaks, J. E., Levy, S. R., \& Dweck, C. S. (2009). Lay theories of personality: Cornerstones of meaning in social cognition. Social and Personality Psychology Compass, 3(6), 1069-1081. doi:10.1111/j.1751-9004.2009.00222.x

Powers, W. T. (1973). Feedback: Beyond behaviorism. Science, 179(4071), 351-356.

Powers, W. T. (1990). Control theory: A model of organisms. System Dynamics Review, 6(1), 1-20.
Reiss, S. (2004). Multifaceted nature of intrinsic motivation: The theory of 16 basic desires. Review of General Psychology, 8(3), 179-193.

Roberts, B. W., \& Mroczek, D. (2008). Personality trait change in adulthood. Current Directions in Psychological Science, 17(1), 31-35. doi:10.1111/j.1467-8721.2008.00543.x

Rothbart, M. K. (2007). Temperament, development, and personality. Current Directions in Psychological Science, 16(4), 207-212. doi:10.1111/j.1467-8721.2007.00505.x

Royce, J. R., \& Powell, A. (1981a). An overview of a multifactor-system theory of personality and individual differences: I. the factor and system models and the hierarchical factor structure of individuality. Journal of Personality and Social Psychology, 41(4), 818-829.

Royce, J. R., \& Powell, A. (1981b). An overview of a multifactor-system theory of personality and individual differences: II. system dynamics and person-situation interactions. Journal of Personality and Social Psychology, 41(5), 10191030.

Sell, A., Hone, L., \& Pound, N. (2012). The importance of physical strength to human males. Human Nature, 23(1), 30-44. doi:10.1007/s12110-012-9131-2

Sheldon, K. M., Cheng, C., \& Hilpert, J. (2011). Understanding well-being and optimal functioning: Applying the multilevel personality in context (MPIC) model. Psychological Inquiry, $22,1-16$.

Sheldon, K. M. (2011). Consilience within the biopsychosocial system. Psychological Inquiry, 22(1), 52-65. doi:10.1080/1047840X.2011.551105

Sheldon, K. M., \& Kasser, T. (1995). Coherence and congruence: Two aspects of personality integration. Journal of Personality and Social Psychology, 68(3), 531-543.

Skinner, N., \& Brewer, N. (2004). Adaptive approaches to competition: Challenge appraisals and positive emotion. Journal of Sport \& Exercise Psychology, 26(2), 283-305.

Smith, M. (2012). Madness in the USA from the gilded age to the progressive era. History of Psychiatry, 23(4), 496-501. doi:10.1177/0957154X12462957

Torges, C. M., Stewart, A. J., \& Duncan, L. E. (2008). Achieving ego integrity: Personality development in late midlife. Journal of Research in Personality, 42(4), 1004-1019. doi:10.1016/j.jrp.2008.02.006

Twenge, J. M., Zhang, L., \& Im, C. (2004). It's beyond my control: A cross-temporal meta-analysis of 
increasing externality in locus of control, 19602002. Personality and Social Psychology Review, 8(3), 308-319. doi:10.1207/s15327957pspr0803_5

Vallacher, R. R., \& Wegner, D. M. (1989). Levels of personal agency: Individual variation in action identification. Journal of Personality and Social Psychology, 57(4), 660-671. doi:10.1037/00223514.57.4.660

Vallacher, R. R., \& Wegner, D. M. (2000). What do people think they are doing? action identification and human behavior. In E. T. Higgins, \& A. W. Kruglanski (Eds.), (pp. 215-228). New York, NY US: Psychology Press.

Vazire, S., \& Mehl, M. R. (2008). Knowing me, knowing you: The accuracy and unique predictive validity of self-ratings and other-ratings of daily behavior. Journal of Personality and Social Psychology, 95(5), 1202-1216. doi:10.1037/a0013314

Von Bertalanffy, L. (1950). An outline of general system theory. British Journal for the Philosophy of Science, 1, 134-165. doi:10.1093/bjps/I.2.134

Von Bertalanffy, L. (1951). Theoretical models in biology and psychology. Journal of Personality, 20, 24-38. doi:10.1111/j.14676494.1951.tb01511.x

Wang, Q., Bowling, N. A., \& Eschleman, K. J. (2010). A meta-analytic examination of work and general locus of control. Journal of Applied Psychology,
95(4), 761-768. doi:10.1037/a0017707; 10.1037/a0017707.supp (Supplemental)

Weinberger, D. A., Schwartz, G. E., \& Davidson, R. J. (1979). Low-anxious, high-anxious, and repressive coping styles: Psychometric patterns and behavioral and physiological responses to stress. Journal of Abnormal Psychology, 88(4), 369-380. doi:10.1037/0021-843X.88.4.369

Wilson, T. D. (2009). Know thyself. Perspectives on Psychological Science (Wiley-Blackwell), 4(4), 384-389. doi:10.1111/j.1745-6924.2009.01143.x

Winter, D. G., \& Stewart, A. J. (1995). Commentary: Tending the garden of personality. Journal of Personality, 63(3), 711-727.

Wundt, W. (1897). Outlines of psychology (C. H. Judd Trans.). Leipzig, Germany: Wilhelm Englemann.

Zebrowitz, L. A. (2006). Finally, faces find favor. Social Cognition, 24(5), 657-701. doi:10.1521/soco.2006.24.5.657

Zimbardo, P. G., \& Boyd, J. N. (1999). Putting time in perspective: A valid, reliable individualdifferences metric. Journal of Personality and Social Psychology, 77(6), 1271-1288. doi:10.1037/0022-3514.77.6.1271

Zuckerman, M., Kuhlman, D. M., Joireman, J., Teta, P., \& Kraft, M. (1993). A comparison of three structural models for personality: The big three, the big five, and the alternative five. Journal of Personality and Social Psychology, 65(4), 757768. doi:10.1037/0022-3514.65.4.757 
Table 1. Five Focal Areas of Research in Personality Psychology

\begin{tabular}{|c|c|c|c|c|}
\hline $\begin{array}{c}\text { FOCAL } \\
\text { AREA }\end{array}$ & Key Activity & Associated Goals & Methods Employed & Examples \\
\hline (5) & $\begin{array}{l}\text { To understand the } \\
\text { longer-term } \\
\text { developmental } \\
\text { changes that } \\
\text { personality } \\
\text { undergoes }\end{array}$ & $\begin{array}{l}\text { - To work through } \\
\text { developmental phases } \\
\text { and stages of personal } \\
\text { growth and change }\end{array}$ & $\begin{array}{l}\text { - Longitudinal } \\
\text { research studies } \\
\text { focusing on } \\
\text { personality } \\
\text { development }\end{array}$ & $\begin{array}{l}\text { - Psychosocial stages } \\
\text { of growth } \\
\text { - Social and } \\
\text { occupational } \\
\text { develop-mental } \\
\text { stages people } \\
\text { experience over } \\
\text { adulthood }\end{array}$ \\
\hline (A) & $\begin{array}{l}\text { To model } \\
\text { personality, and to } \\
\text { use such models to } \\
\text { predict key } \\
\text { outcomes of } \\
\text { personality }\end{array}$ & $\begin{array}{l}\text {-To develop "high- } \\
\text { level models of } \\
\text { personality" that } \\
\text { examine its key parts, } \\
\text { overall dynamics and } \\
\text { development } \\
\text {-To make predictions } \\
\text { from personality to } \\
\text { key outcomes }\end{array}$ & $\begin{array}{l}\bullet \text { Verbal-descriptive } \\
\text { theoretical } \\
\text { propositions } \\
\text {-Mathematical } \\
\text { models of how the } \\
\text { key variables of } \\
\text { personality fit } \\
\text { together and predict } \\
\text { important outcomes }\end{array}$ & $\begin{array}{l}\bullet \text { (Historical) Freud's } \\
\text { theory of id, ego, and } \\
\text { superego and their } \\
\text { impact on } \\
\text { psychological health } \\
\text { - Structural equation } \\
\text { modeling of sets of } \\
\text { variables and how } \\
\text { they predict key } \\
\text { outcomes (e.g., well- } \\
\text { being, occupational } \\
\text { success) }\end{array}$ \\
\hline (3) & $\begin{array}{l}\text { To identify and } \\
\text { organize key sets of } \\
\text { personality } \\
\text { variables }\end{array}$ & $\begin{array}{l}\text { - To map interrelations } \\
\text { among variables } \\
\text { - To identify key } \\
\text { groups of variables }\end{array}$ & $\begin{array}{l}\text {-Multivariate } \\
\text { techniques such as } \\
\text { factor analysis and } \\
\text { multidimensional } \\
\text { scaling } \\
\text {-Conceptual } \\
\text { organizations }\end{array}$ & $\begin{array}{l}\text {-Use the lexical } \\
\text { hypothesis to identify } \\
\text { the "Big Five" } \\
\text { •Examine } \\
\text { expressions of } \\
\text { personality in the } \\
\text { environment }\end{array}$ \\
\hline (2) & $\begin{array}{l}\text { To identify } \\
\text { important } \\
\text { personality } \\
\text { variables }\end{array}$ & $\begin{array}{l}\text {-To identify and } \\
\text { define a specific } \\
\text { variable } \\
\text { - To create a valid } \\
\text { measure of a variable }\end{array}$ & $\begin{array}{l}\text {-Theories for } \\
\text { identifying key } \\
\text { variables } \\
\text {-Applications of } \\
\text { theories of reliability } \\
\text { and validity }\end{array}$ & $\begin{array}{l}\text {-Define and measure } \\
\text { extraversion; } \\
\text { examine its correlates } \\
\text {-Define and measure } \\
\text { possible selves; } \\
\text { examine their } \\
\text { correlates }\end{array}$ \\
\hline (1) & $\begin{array}{l}\text { To study how } \\
\text { people observe and } \\
\text { perceive personality }\end{array}$ & $\begin{array}{l}\text {-To create a } \\
\text { description of how we } \\
\text { know personality } \\
\text {-To examine how } \\
\text { people perceive } \\
\text { personality }\end{array}$ & $\begin{array}{l}\text {-Zero-acquaintance } \\
\text { and extended- } \\
\text { acquaintance studies } \\
\bullet \text { Memory research }\end{array}$ & $\begin{array}{l}\text {-Zero-acquaintance } \\
\text { accuracy and } \\
\text { inaccuracy } \\
\text {-First impression } \\
\text { research }\end{array}$ \\
\hline
\end{tabular}




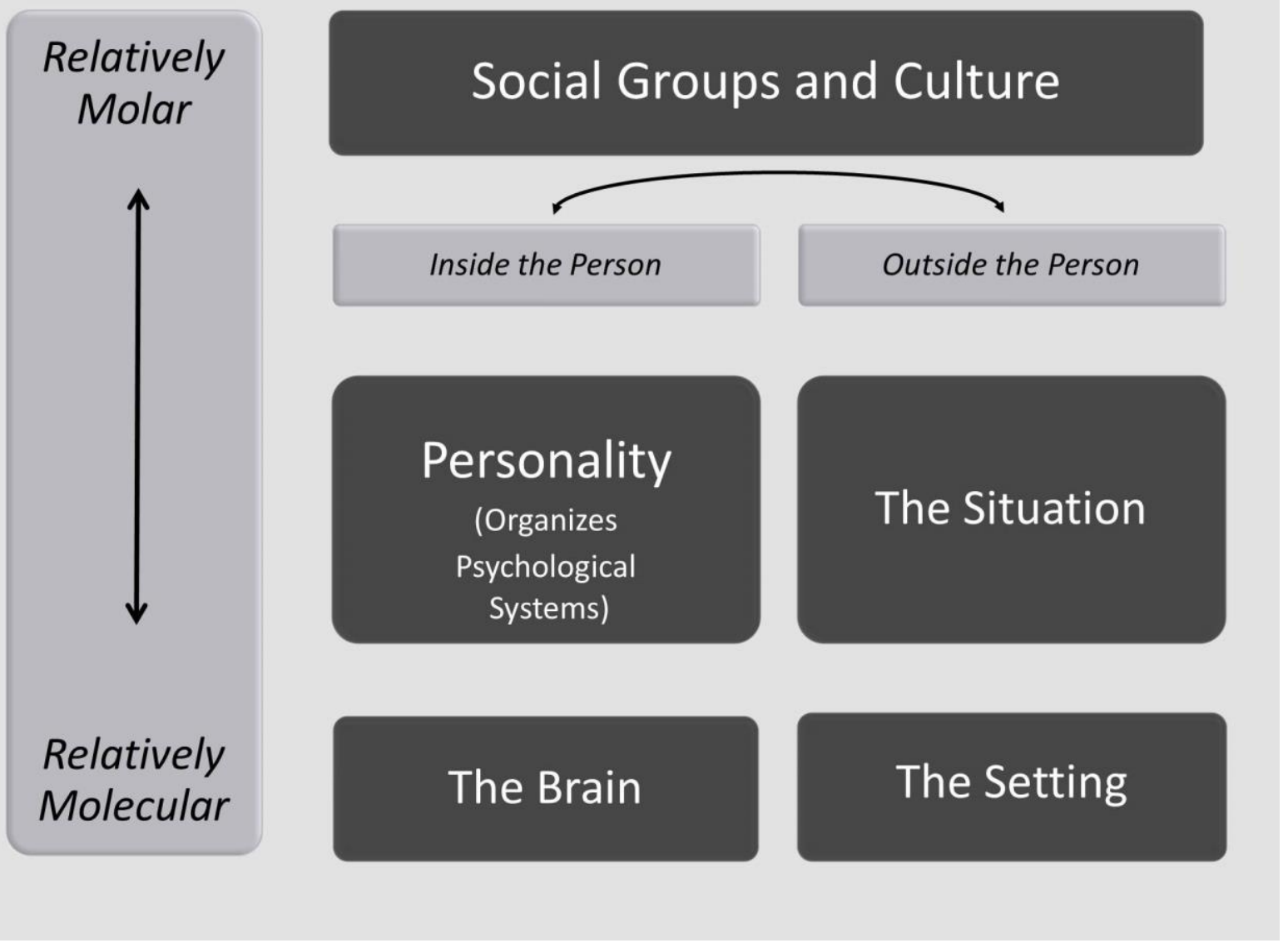

Figure 1: Personality amidst its surrounding systems. Personality and its surrounding systems are depicted in two dimensions. A molecular-molar dimension runs vertically and indicates that personality emerges from the brain and major psychological systems; also, situations emerge from the settings in which they are situated. The second inner-outer dimension separates personality--located inside the individual - from the external setting of the person and the situation with which the individual interacts. Figure adapted from "A Tale of Two Visions: Can a New View of Personality Help Integrate Psychology?,” by J. D. Mayer, 2005, American Psychologist, 60, p. 297, and “A Really Big Picture of Personality," J. D. Mayer and M. Korogodsky, 2011, Social and Personality Psychology Compass, 5, p. 107. Copyright 2005 by American Psychological Association and 2011 by the authors, Social and Personality Psychology Compass, and Blackwell Publishing Ltd. 


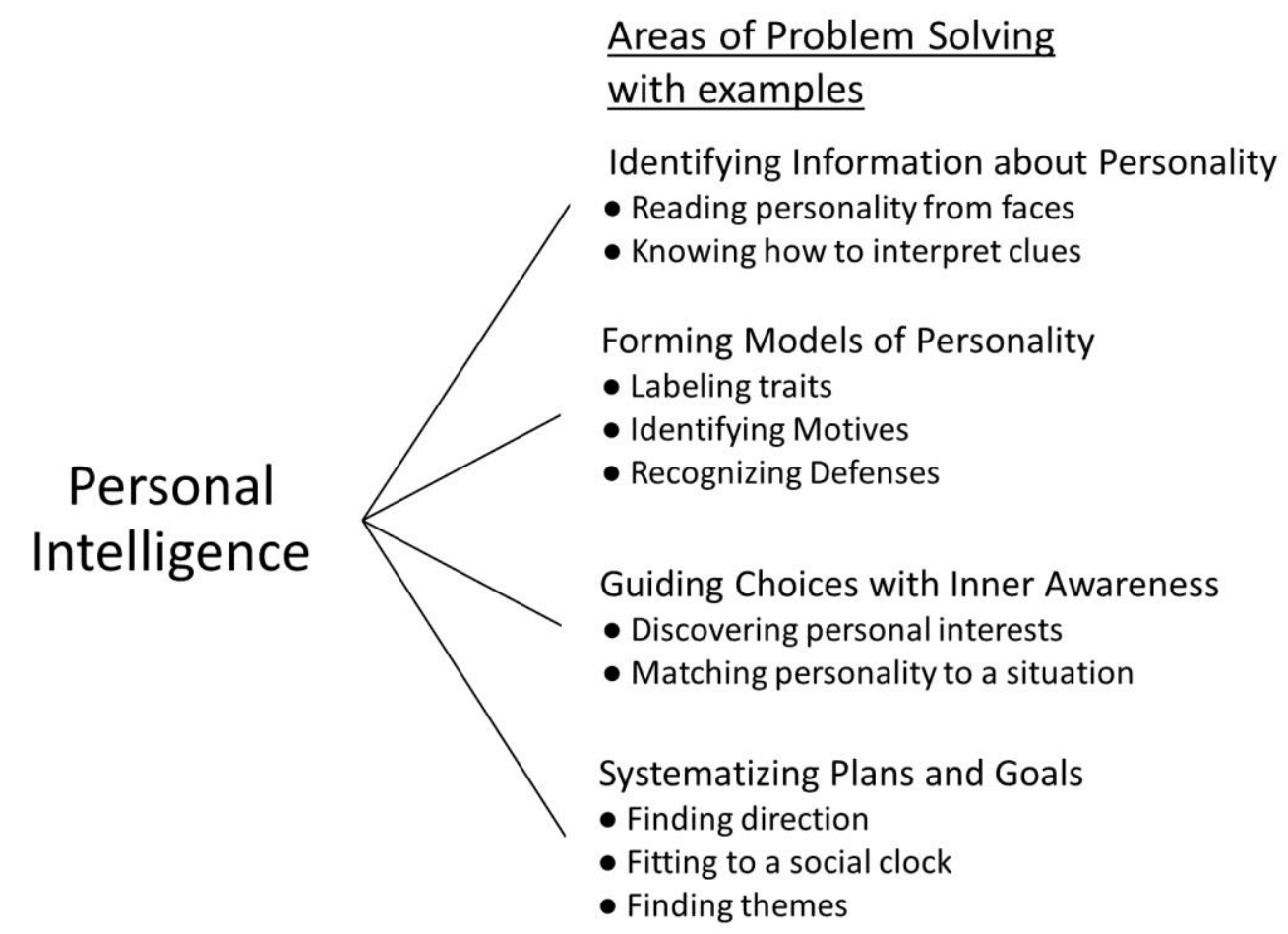

Reprinted with permission from Mayer (2014). Copyright John D. Mayer and Scientific American / Farrar, Strauss Giroux

Figure 2: The four areas of personal intelligence. We apply our personal intelligence to four areas of problem-solving: identifying information about personality, forming accurate models of personality, guiding choices with inner awareness, and systematizing plans and goals. Each area can be further divided into more specific areas as indicated in the diagram. 
Figure 3

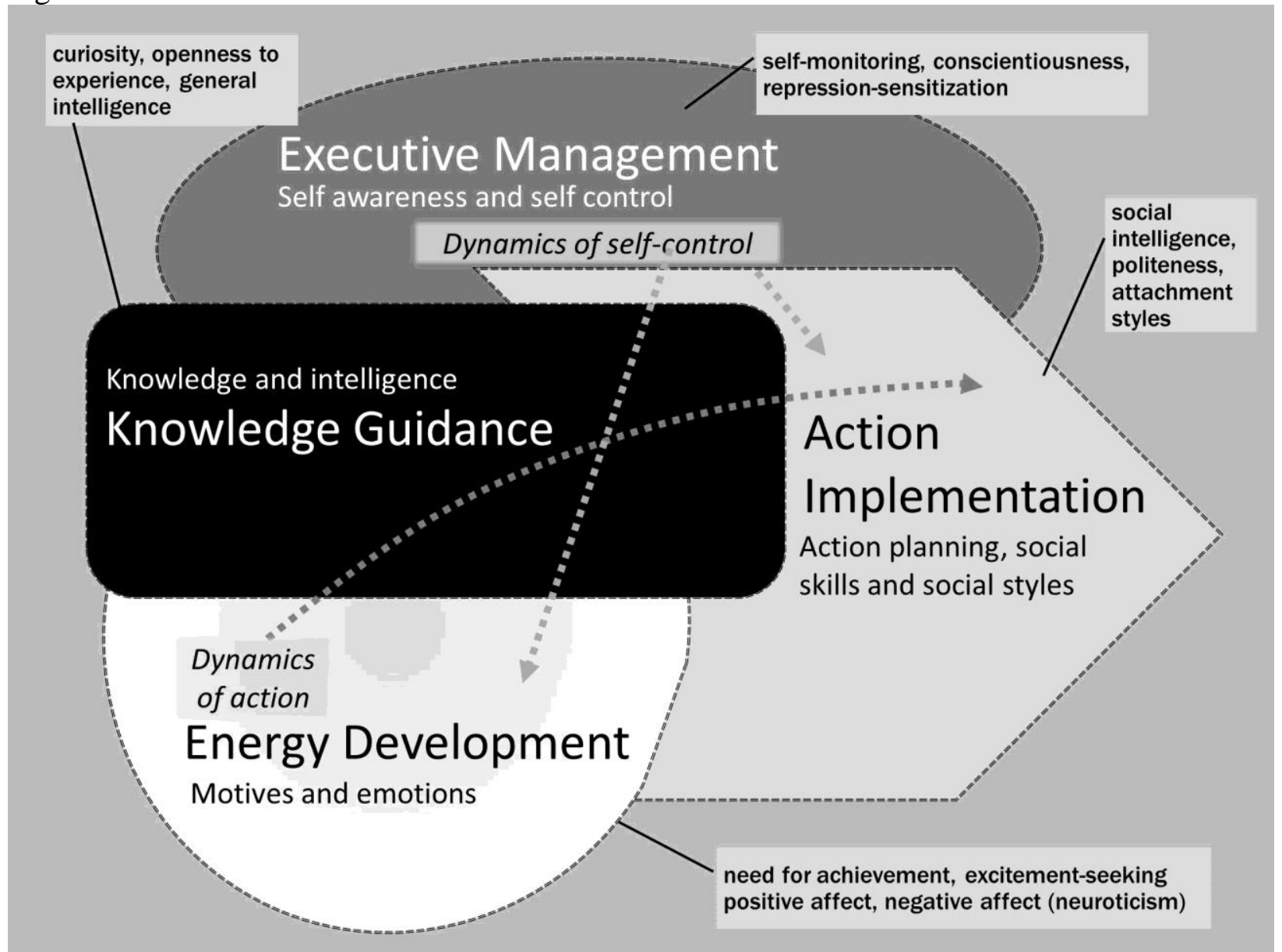

Figure 3: The systems set division of personality into major functional areas. The four areas of energy development, knowledge guidance, executive management and action implementation are depicted, as are selected examples of traits that relate to each of the four areas (additional traits, not shown, are blends of two or more areas; for example, extraversion represents a blend of positive emotion and social style). Dynamics of self-control and dynamics of action are represented by dotted lines. Adapted from "A Tale of Two Visions: Can a New View of Personality Help Integrate Psychology?” by J. D. Mayer, 2005, American Psychologist, 60, p. 300 and "A Really Big Picture of Personality," J. D. Mayer and M. Korogodsky, 2011, Social and Personality Psychology Compass, 5, p. 112. Copyright 2005 by American Psychological Association and 2011 by the authors, Social and Personality Psychology Compass, and Blackwell Publishing Ltd. 